\title{
Effect of Integrated Nutrient Management on Growth and Yield of Cluster Bean (Cyamopsis tetragonoloba) Var. Pua Navbahar
}

\author{
Usha Sharma*, Arun A. David and Upendra Singh \\ Department of Soil Science, Sam Higginbottom Institute of Agriculture, Technology and \\ Sciences (Deemed-to-be-University), Allahabad, 211007 U. P., India \\ *Corresponding author
}

A B S T R A C T

\section{Keywords}

Cluster bean, Integrated nutrient, Soil properties, Yield attributes

Article Info

Accepted: 04 June 2018 Available Online: 10 July 2018
An field experiment was conducted during Kharif season 2014-15 at the Research farm of Soil Science, Allahabad School of Agriculture, laid out in factorial randomized block design, consisted twelve treatment and three replications. It was observed that growth and yield of cluster bean in treatment was $\mathrm{T}_{11} \mathrm{~L}_{2} \mathrm{~V}_{1} \mathrm{R}_{1}$ (@ $\mathrm{N}_{20} \mathrm{P}_{40} \mathrm{~K}_{40}$ NPK kg ha ${ }^{-1}+10 \mathrm{t}$ vermicompost ha ${ }^{-1}+200 \mathrm{~g}$ Rhizobium $10 \mathrm{~kg}^{-1}$ seed was maximum. Maximum plant height $85.77 \mathrm{~cm}$, no. of leaves plant ${ }^{-1} 70.22$, number of cluster plant ${ }^{-1} 11.33$, number of pod cluster $^{-1} 10.10$, number of seed $\operatorname{pod}^{-1} 9.77$, length of pod 13.93, pod yield $76 \mathrm{qha}^{-1}$ were found to be nonsignificant over all other treatments. Adequate plant nutrient supply holds the key for improving the food grain production and sustaining soil fertility.

\section{Introduction}

Cluster bean [Cyamopsis tetragonoloba (L.) Taub] Var. Pusa Navbahar] popularly known as "Guar" is a vegetative crop of Indian origin belonging to the family fabaceae. It is important legume crop mainly grown under rainfed condition in arid and semi-regions of Rajasthan during kharif season. It is very hardy and drought tolerant crop. Its deep penetrating roots enable the plant to utilize available moisture more efficiently and thus offer better scope for rainfed cropping. The crop also survives even at moderate salinity and alkalinity conditions. There is no other legume crop so hardy and drought tolerant as cluster bean, which is especially suited for soil and climate of Rajasthan. It has high calorific and nutritive value and its seed contains 28$32 \%$ of gum (Kherawat et al., 2013).

Nitrogen is the most important nutrient for plant growth and development. Nitrogen also plays an important role in synthesis of chlorophyll and amino acid, which contributes to the building units of protein and thus the growth of plants. Insufficient nitrogen may reduce yield drastically and deteriorates the quality of produce. The nitrogen application increased crude protein, crude fibre contents, 
ash percentage, carbohydrates, leaf area per plant, dry matter and green fodder yield of cluster bean cultivars (Ayub et al., 2010).

The phosphorus is the second important plant nutrients. An application of phosphorus influences symbiotic nitrogen fixation yield and quality of cluster pods. Phosphorus has a positive and significant effect on nodulation and crop yield. Phosphorus enhances the activity of Rhizobia. Phosphorus also improves the quality of cluster bean grain.

The potassium is the 3rd most important essential nutrient after nitrogen and phosphorus. The potassium activates more than 60 enzymes and enzymatically catalyzes the system involved in photosynthesis, metabolism and translocation of carbohydrates and proteins, membrane permeability, stomatal regulation and water utilization. Other benefits ascribed to $\mathrm{K}$ include resistance of plants against pests, disease and stresses caused by drought, frost, salinity, sodicity and in assuring improved crop quality characteristics (Kherawat et al., 2013).

Vermicomposts are products derived from the accelerated biological degradation of organic wastes by earthworms and microorganisms. The process accelerates the rates of decomposition of the organic matter, alter the physical and chemical properties of the material, leading to a humification effect in which the unstable organic matter is fully oxidized and stabilized vermicompost are finely divided peat-like materials with high porosity, aeration, drainage, water-holding capacity. These materials contained mineral contents (\% dry weight) ranging from 2.2-3.0 $\mathrm{N}$, 0.4-2.9 P, 1.7-2.5 K, and 1.2-9.5 Ca compared to those of a commercial plant growth (Norman et al., 2005).

In the view of maintaining the soil health and quality of produce, application of bio-fertilizer plays a vital role. Biofertilizer is microbial inoculants of selective microorganisms like bacteria, fungi already existing in nature. Biofertilizer cannot replace chemical fertilizer but can meet the increasing demand of chemical fertilizer with its supplementary and complementary use, besides improving physio-chemical properties of soil and also improves the efficiency of applied fertilizer. Biofertilizers enrich soil fertility and improves soil fertility (Deshmukh et al., 2014).

\section{Materials and Methods}

The experiment was conducted during Kharif season 2014-15 on crop research farm of department of Soil Science at Sam Higginbottom Institute of Agriculture, Technology and Sciences, Deemed-to-beUniversity Allahabad, the area is situated on the south of Allahabad on the right side of the river Yamuna on the South of Rewa road at a distance of about $6 \mathrm{Km}$ from Allahabad city. It is situated at $25^{\circ} 24 ' 23^{\prime \prime} \mathrm{N}$ latitude, $81^{0} 50$ ' $38^{\prime \prime} \mathrm{E}$ longitude and at the altitude of 98 meter above the sea level (MSL).

The treatment consisted of twelve combination of organic and inorganic source of fertilizers $\mathrm{T}_{0}\left(\mathrm{~L}_{0} \mathrm{~V}_{0} \mathrm{R}_{0}\right)$ Control, $\mathrm{T}_{1}\left(\mathrm{~N}_{0} \mathrm{P}_{0} \mathrm{~K}_{0}\right.$ + vermicompost $t_{0}$ and Rhizobium @ 200 g/10 $\mathrm{Kg}$ seed $), \mathrm{T}_{2}\left(\mathrm{~N}_{0} \mathrm{P}_{0} \mathrm{~K}_{0}+\right.$ vermicompost @ $10 \mathrm{t}$ ha $^{-1}$ and Rhizobium $), \mathrm{T}_{3} \quad\left(\mathrm{~N}_{0} \mathrm{P}_{0} \mathrm{~K}_{0}+\right.$ vermicompost@10 t ha ${ }^{-1}$ and Rhizobium @ $200 \mathrm{~g} / 10 \mathrm{Kg}$ seed $), \mathrm{T}_{4}\left(\mathrm{~N}_{10} \mathrm{P}_{20} \mathrm{~K}_{20} \mathrm{Kg} \mathrm{ha}^{-1}+\right.$ vermicompost $_{0}$ and Rhizobium $)_{0}, \mathrm{~T}_{5}$ $\left(\mathrm{N}_{10} \mathrm{P}_{20} \mathrm{~K}_{20} \mathrm{Kg} \mathrm{ha}{ }^{-1}+\right.$ vermicompost $_{0}$ and Rhizobium @200g/10 Kg seed), $\mathrm{T}_{6}\left(\mathrm{~N}_{10} \mathrm{P}_{20} \mathrm{~K}_{20}\right.$ $\mathrm{Kg} \mathrm{ha}{ }^{-1}+$ vermicompost @ $10 \mathrm{t} \mathrm{ha}^{-1}$ and Rhizobium $\left._{0}\right), \quad \mathrm{T}_{7} \quad\left(\mathrm{~N}_{10} \mathrm{P}_{20} \mathrm{~K}_{20} \quad \mathrm{Kg} \quad\right.$ ha $^{-1}+$ vermicompost@10 t ha ${ }^{-1}$ and Rhizobium @ $200 \mathrm{~g} / 10 \mathrm{Kg}$ seed $), \mathrm{T}_{8}\left(\mathrm{~N}_{20} \mathrm{P}_{40} \mathrm{~K}_{40} \mathrm{Kg} \mathrm{ha}^{-1}+\right.$ vermicompost $_{0}$ and Rhizobium 0 ), $\mathrm{T}_{9}$ $\left(\mathrm{N}_{20} \mathrm{P}_{40} \mathrm{~K}_{40} \mathrm{Kg} \mathrm{ha}{ }^{-1}+\right.$ vermicompost $_{0}$ and Rhizobium @ $200 \quad \mathrm{~g} / 10 \quad \mathrm{Kg}$ seed), $\mathrm{T}_{10}$ $\left(\mathrm{N}_{20} \mathrm{P}_{40} \mathrm{~K}_{40} \mathrm{Kg} \mathrm{ha}^{-1}+\right.$ vermicompost @ $10 \mathrm{t}$ 
ha $^{-1}$ and Rhizobium $), \mathrm{T}_{11}\left(\mathrm{~N}_{20} \mathrm{P}_{40} \mathrm{~K}_{40} \mathrm{Kg} \mathrm{ha}^{-1}+\right.$ vermicompost@10 tha ${ }^{-1}$ and Rhizobium @ $200 \mathrm{~g} / 10 \mathrm{Kg}$ seed). The trial was laid out in $3 \times 2 \times 2$ factorial randomized block design with three replication, plot size having $2 \times 2 \mathrm{~m}$ for crop seed rate is $15-20 \mathrm{~kg} \mathrm{ha}^{-1}$ (Cyamopsis tetragonoloba L.) Var. Pusa Navbahar. Cluster bean grows in $16^{\text {th }}$ July month 2014 and the source of nitrogen, phosphorus, potassium, vermicompost and Rhizobium culture as Urea, SSP, MOP, respectively. Basal dose of fertilizer was applied in respective plots according to treatment allocation unifurrows opened by about $5 \mathrm{~cm}$. The seeds were then treated with Rhizobium (@ 200 g Rhizobium $/ 10 \mathrm{~kg}$ seed). The inoculated seeds were dried under shade and sown immediately after drying. All the agronomic practices were carried out uniformly to raise the crop. The crop was harvested on $17^{\text {th }}$ October. During the course of experiment, cluster bean plant data were taken at 30, 45 and 60 days after sowing (DAS).

\section{Results and Discussion}

The results given in Table 1 indicate some of the important parameters of plant height $(\mathrm{cm})$, number of leaves plant ${ }^{-1}$ and number of cluster plant $^{-1}$ of cluster bean crop. The maximum plant height $(\mathrm{cm})$, number of leaves plant ${ }^{-1}$ and number of cluster plant ${ }^{-1}$ were recorded 85.77 $\mathrm{cm}, 70.22$, and 11.33, respectively, at 60 DAS in the treatment $T_{11}$ that was non significantly higher as compared to other treatment combination. Plant height $(\mathrm{cm})$, number of leaves plant ${ }^{-1}$ and number of cluster plant ${ }^{-1}$ of cluster bean crop were increased non significantly and progressively with the increasing level of NPK, vermicompost and Rhizobium at 60 DAS was found to be non significant.

Table.1 Effect of different levels of N P K, Vermicompost and Rhizobium on growth and yield of cluster bean (Cyamopsis tetragonoloba L.) at $60 \mathrm{DAS}$

\begin{tabular}{|c|c|c|c|c|c|c|c|}
\hline $\begin{array}{l}\text { Treatment } \\
\text { combination }\end{array}$ & $\begin{array}{l}\text { Plant hight } \\
(\mathrm{cm})\end{array}$ & $\begin{array}{l}\text { No. of } \\
\text { leaves }\end{array}$ & $\begin{array}{l}\text { No. of } \\
\text { cluster } \\
\text { plant }^{-1}\end{array}$ & $\begin{array}{l}\text { No. of } \\
\text { pod } \\
\text { cluster }^{-1}\end{array}$ & $\begin{array}{l}\text { No. of } \\
\text { seed } \\
\text { pod }^{-1}\end{array}$ & $\begin{array}{l}\text { Length } \\
\text { of pod } \\
(\mathrm{cm})\end{array}$ & $\begin{array}{l}\text { Pod yield } \\
\left(\mathrm{qha}^{-1}\right)\end{array}$ \\
\hline $\mathbf{T}_{0}\left(\mathbf{L}_{0} \mathbf{V}_{0} \mathbf{R}_{0}\right)$ & 72.88 & 60.77 & 5.33 & 4.66 & 4.99 & 9.99 & 28.16 \\
\hline$T_{1}\left(L_{0}+V_{0}+R_{1}\right)$ & 73.77 & 61.33 & 5.66 & 5.10 & 5.44 & 10.14 & 30.66 \\
\hline$T_{2}\left(L_{0}+V_{1}+R_{0}\right)$ & 74.99 & 63.00 & 6.33 & 5.55 & 5.77 & 10.59 & 36.00 \\
\hline$T_{3}\left(L_{0}+V_{1}+R_{1}\right)$ & 76.33 & 63.44 & 6.55 & 5.88 & 6.10 & 10.86 & 37.83 \\
\hline$T_{4}\left(L_{1}+V_{0}+R_{0}\right)$ & 77.66 & 64.33 & 6.99 & 6.33 & 6.21 & 11.28 & 39.00 \\
\hline$T_{5}\left(L_{1}+V_{0}+R_{1}\right)$ & 78.44 & 64.99 & 7.33 & 6.66 & 6.77 & 11.73 & 41.00 \\
\hline$T_{6}\left(L_{1}+V_{1}+R_{0}\right)$ & 79.00 & 65.55 & 7.88 & 6.99 & 7.10 & 12.13 & 43.08 \\
\hline $\mathbf{T}_{7}\left(\mathrm{~L}_{1}+\mathrm{V}_{1}+\mathbf{R}_{1}\right)$ & 80.66 & 66.66 & 8.33 & 7.44 & 7.55 & 12.38 & 47.16 \\
\hline$T_{8}\left(L_{2}+V_{0}+R_{0}\right)$ & 81.77 & 67.21 & 8.77 & 7.77 & 7.77 & 12.89 & 53.83 \\
\hline$T_{9}\left(L_{2}+V_{0}+R_{1}\right)$ & 82.77 & 67.99 & 9.33 & 8.11 & 8.21 & 13.22 & 58.16 \\
\hline$T_{10}\left(L_{2}+V_{1}+R_{0}\right)$ & 84.21 & 68.88 & 10.32 & 9.22 & 9.21 & 13.62 & 67.08 \\
\hline$T_{11}\left(L_{2}+V_{1}+R_{1}\right)$ & 85.77 & 70.22 & 11.33 & 10.10 & 9.77 & 13.93 & 76.00 \\
\hline F- test & NS & NS & NS & NS & NS & NS & NS \\
\hline S. Ed ( $( \pm)$ & 0.84 & 0.42 & 0.36 & 0.44 & 0.56 & 0.56 & 0.25 \\
\hline C. D. at $5 \%$ & - & - & - & 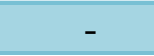 & - & - & - \\
\hline
\end{tabular}


The results given in Table 1 indicate some of the important parameters number of pod cluster $^{-1}$, number of seed pod ${ }^{-1}$, length of pod and pod yield $\mathrm{qha}^{-1}$ of cluster bean crop. The maximum number of pod cluster ${ }^{-1}$, number of seed pod $^{-1}$, length of pod and pod yield $\mathrm{q} \mathrm{ha}^{-1}$ were recorded 10.10, 9.77, 13.93, and 76, respectively, in the treatment $T_{11}$ that was non significantly higher as compared to other treatment combination. The number of pod cluster $^{-1}$, number of seed pod ${ }^{-1}$, length of pod and pod yield $\mathrm{q} \mathrm{ha}^{-1}$ of cluster bean crop were increased non significantly and progressively with the increasing level of NPK, vermicompost and Rhizobium was found to be non significant.

It was concluded from trial that the various level of N P K, Vermicompost and Rhizobium seed inoculation used from different sources in the experiment, the treatment combination $\mathrm{T}_{11}\left(\mathrm{~N}_{20} \mathrm{P}_{40} \mathrm{~K}_{40} \mathrm{Kg} / \mathrm{ha}\right.$, vermicompost @ 10 t/ha, and Rhizobium @ $200 \mathrm{~g} / 10 \mathrm{Kg}$ seed)was found to be the best, in increasing plant height $85.77 \mathrm{~cm}$, number of leaves plant $^{-1} 70.22$, number of cluster plant ${ }^{-1} 11.33$, number of pod cluster ${ }^{-1} 10.10$, number of seed pod $^{-1}$ 9.77, length of pod 13.93, pod yield $76 \mathrm{qha}^{-1}$. The treatment $T_{11}$ that was non significantly higher as compared to other treatment combinations.

\section{Acknowledgement}

The Authors are grateful to the Department of
Soil Science, Allahabad School of Agriculture, for taking their keep interest and encouragement to carry out the research work at Sam Higginbottom Institute of Agriculture, Technology and Sciences Allahabad-211007 (U.P.) India.

\section{References}

Ayub, M., Tahir, Ather Nadeem, M., Arif Zubair, M., Tariq M., and Ibrahim M. (2010). Effect of Nitrogen Applications on Growth, Forage Yield and Quality of Three Cluster Bean Varieties. Pak. J. Life Soc. Sci. 8 (2): 111-116.

Deshmukh, R.P., Nagre, P.K., Wagh, A.P. and Dod, V.N. (2014). Effect of Different Bio- fertilizers on Growth, Yield and Quality of Cluster bean Indian Journal of Advances in Plant Research (IJAPR) Vol. 1 (2): - 39-42; ISSN: 2347-8918.

Kherawat, B.S., Munna lal, Agarwal M.,. Yadav H.K. And Sushil Kumar (2013). Effect of Applied Potassium and Manganese on Yield and Uptake of Nutrients by Cluster bean (Cyanosis tetragonoloba). Journal of Agricultural Physics Vol. 13, No. 1, pp. 22-26.

Norman Q. Arancon and Clive A. Edwards, (2005) Soil Ecology Laboratory, The Ohio State University, Columbus, $\mathrm{OH}$ 43210 USA.

\section{How to cite this article:}

Usha Sharma, Arun A. David and Upendra Singh. 2018. Effect of Integrated Nutrient Management on Growth and Yield of Cluster Bean (Cyamopsis tetragonoloba) Var. Pua Navbahar. Int.J.Curr.Microbiol.App.Sci. 7(07): 350-353. doi: https://doi.org/10.20546/ijcmas.2018.707.042 